\title{
Bank Lending in Project Finance: The New Regulatory Capital Framework
}

\author{
Enzo Scannella \\ Correspondence: Enzo Scannella, Department of Economics, Business and Finance, University of Palermo, \\ Viale delle Scienze, cap. 90128, Palermo, Italy. Tel: 39-91-2389-5305. E-mail: enzo.scannella@unipa.it
}

Received: July 19, $2012 \quad$ Accepted: September 25, $2012 \quad$ Online Published: December 10, 2012

doi:10.5539/ijef.v5n1p218

URL: http://dx.doi.org/10.5539/ijef.v5n1p218

\begin{abstract}
The paper aims to examine the new regulatory framework of project finance in the economics of banking firms. In particular, the paper investigates the uniqueness of the project finance, the significant importance of the project finance in bank activity, and the role of the new bank capital requirements to promote the innovative financial scheme.

In the project finance business loans terms and characteristics are primarily based on the assets and quality of the project to be financed. It means that the usual bank rating models for lending business might not been implemented in the project finance lending. Quantitative estimates of credit risk could not be always possible in project finance lending. Consequently, the new regulatory capital requirements framework gives banks the option to implement a qualitative method - a supervisory slotting criteria approach - to evaluate credit risk in project finance lending business. The regulatory capital requirement recognizes project finance as specialized lending. The paper provides a summary of the treatment of the project finance in the New Basel Capital Accord.

The paper is organized as follows. Section 1 provides a general description of project finance. Section 2 identifies the economic and financial uniqueness of project finance loans and credit risk assessment process. Section 3 delineates the impact of the new regulatory capital requirements framework on project finance lending. Final sections concludes.
\end{abstract}

Keywords: project finance, specialized lending, bank capital requirements, credit risk

\section{Introduction}

Project finance is an innovative financial technique that aims to fund investment project based on the basis of economic and financial characteristic of the project itself, rather than on indebtedness capacity of the promoter of the project.

Usually, the birth of the project finance goes back to the previous century in the United States and, in particular, in the energy and oil extraction. At the international level project finance has been established especially after the Second World War. The application of project finance in the industry and infrastructure sector is more recent (ports, airports, railway works, high speed rail, hospitals, prisons, subways, bridges, roads, environment projects, telecommunication networks, alternative energy plants, power generations plants, chemical processing plants, mines, etc.). This success was due to the privatization process that affected the European countries and the increasingly constraints on public spending that has increased the need for private financial resources.

Project finance during the last decades has become not only an innovative financial instrument but also an instrument of economic policy that aims at encouraging the involvement of private parties in infrastructure financing and management of public utilities (Brealey, Cooper \& Habib, 1996; Comana, 2003; Imperatori, 2003; Khan \& Parra, 2003). The widening, over time, of project finance techniques to different kinds of projects has expanded the technical notion of the project finance. Today, it encompasses some cases that are different from the traditional concept of the project finance. It has mainly occurred in the public sector where public works are entirely financed with public funds. It becomes essential to define the concept of the project finance from a legal and management point of view, in order to better analyze the different configurations assumed by the project finance.

It is complex to give a legal definition of project finance because it is not suitable to frame the project finance within a typical contract. It represents rather a sum of typical contracts, such as supply, sale, procurement, 
financing, etc. In addition, there are agreements with local governments and administrative measures (licenses, permits, concessions, etc). Project finance can not therefore be regarded as a single multilateral contract but as a set of typical contracts which are closely linked (Figure 1). Even though project finance has certain common elements, every project finance operation has unique characteristics that distinguish one from each other. So, it is very difficult to give a general definition, since it has been adapting not only to the objectives of parties involved but also to technical, financial, and economic aspects of the investment projects.

A special purpose vehicle (e.g. a corporation, limited partnership, or other legal form) usually builds and operates a project. The project finance represents a multidisciplinary way to finance specific investments. It is characterized by complexity and a high involvement of bank loans. The main guarantee for the repayment of funds is represented by cash flows of the project. Project finance can be defined as a financing technique in which the main point of reference is the project. The single project has a distinct legal entity. Lenders loan money for a project solely based on the specific project's risks and future cash flows (Altug, Ozler \& Usman, 2002; Beidleman, Fletcher \& Veshosky, 1990; Finnerty, 2007; Wynant, 1980). The project should be able to generate cash flows over time in a sufficient way to repay loans and offer adequate returns on equity. Nevitt (1988) has defined the project finance as a financing technique in which a lender relies on cash flows of the project as the source of funds that will allow the repayment of loans and the return on equity capital. This is the main difference between project finance and corporate finance.

In the project finance the procedure for granting a loan is reversed. In the corporate finance a bank evaluates the possibility to loan money based on the credit standing of the firm. In the project finance a bank decides to fund a project by agreeing that cash flows to service debts are associated with revenues generated from the project, and the guarantees are only represented by the assets of the project and not by all firm's assets. The project lies at the center of all the contractual and financial relationships in the financing scheme. The project is evaluated mainly by private lenders for its ability to generate cash flows.

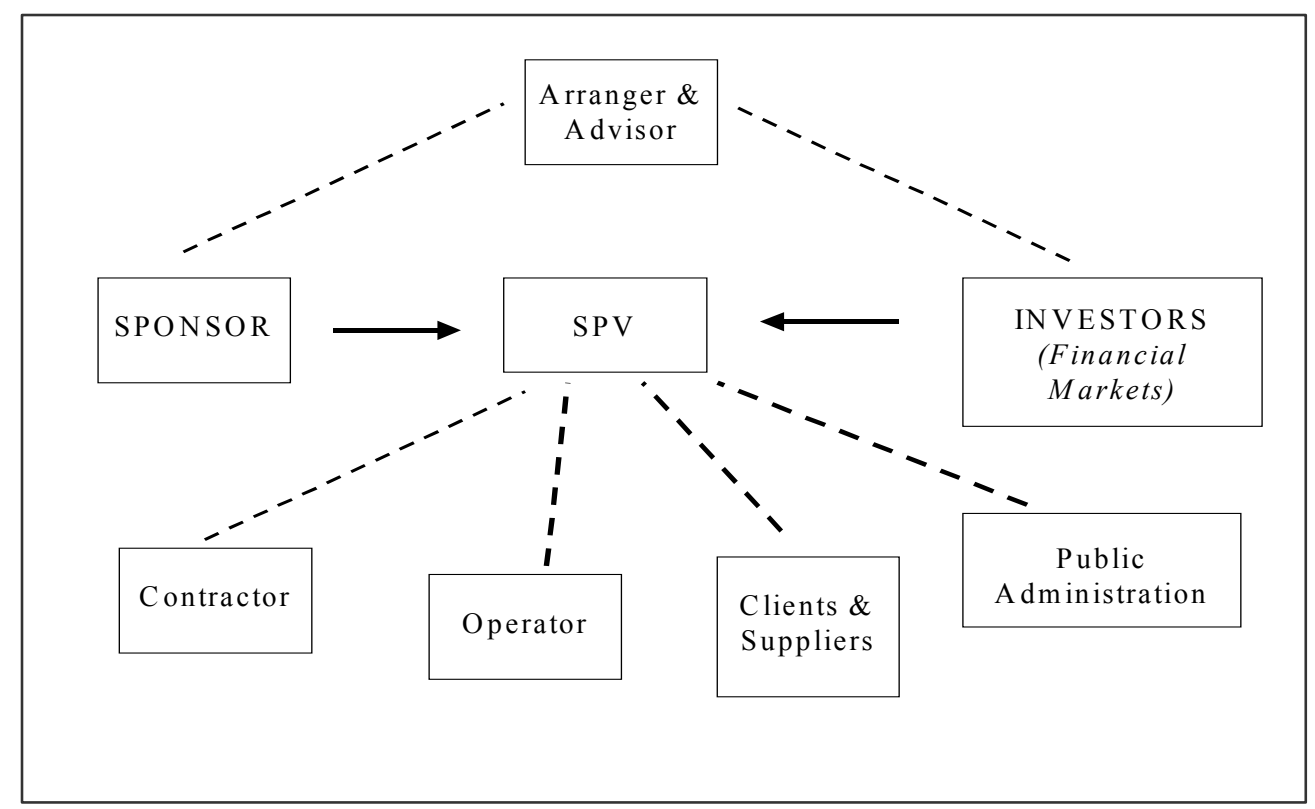

Figure 1. Project Finance: a Comprehensive Scheme

Using project finance involves making a detailed business plan. The plan should quantify cash flows that the investment will generate in the future in order to assess the project's ability to repay debts and equity. In order to do so is necessary to define a credible set of assumptions that should be used as an information base for the estimations of future income statements and balance sheets as well as for the calculations of the expected cash flows generated by the investment project (Figure 2). A set of cash flows scenarios is a basic starting point of every project finance transaction. It has a macroeconomic, industry, and asset specificity. Ideal projects for project financing are those that have relatively predictable and stabile cash flows.

Project finance has proven to be a useful financing technique throughout the world and across many industry sectors (Buljevich \& Park, 1999; Esty, 2002, 2003; Fabozzi \& Nevitt, 2000; Gatti, 2008). As argued before, 
project finance is an innovative model of financing projects. This leads to emphasize the unique attributes of project finance:

a. cash flows of the project must be legally isolated by other activities (ring-fence). It usually is, but not necessarily, realized through the establishment of a corporate vehicle (special purpose vehicle-SPV) to isolate assets in a separate entity;

b. financing decisions are based on the cash flows that the project is expected to generate. The project is financed as a stand-alone entity rather than as part of a corporate balance sheet;

c. expected cash flows must be sufficient to meet debt service (appropriate cover ratios are identified);

d. the risks of the project, that are reflected in a more or less variability of costs and revenues of the project, must be identified, analyzed, evaluated, and distributed among various parties involved in the project. The risk sharing should be realized through a complex system of contracts which reflects a process of negotiation between different stakeholders.

e. projects usually have two main distinct phases (construction and operation) characterized by different risks and cash flows structures.

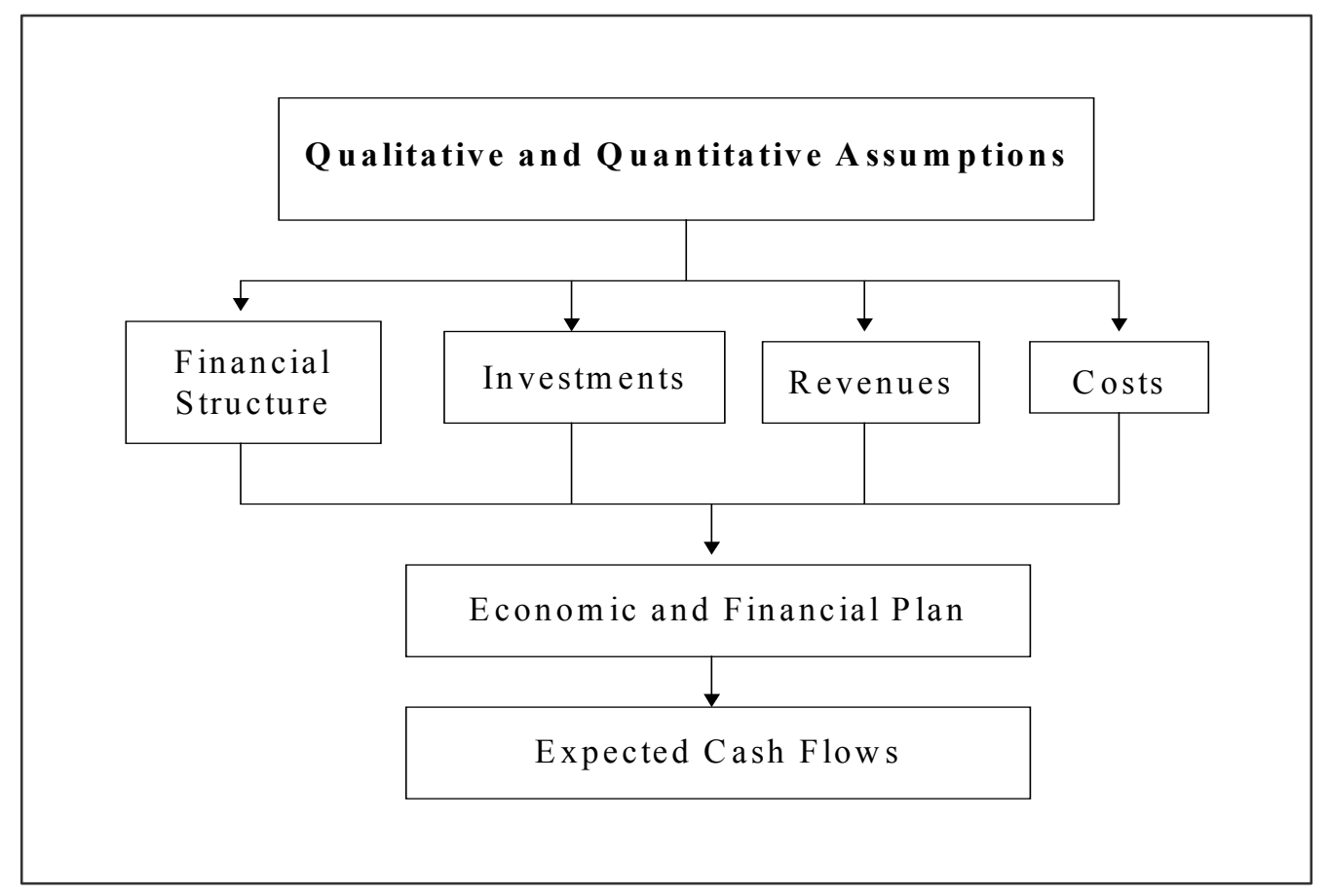

Figure 2. Project Finance: a Flow Structure of Expected Cash Flows

\section{Bank Lending and Credit Risk Assessment in Project Finance}

The de-specialization of banks has led to a greater integration between different segments of financial intermediation: loans, securities and insurance. This was possible thanks to the development of "universal" banks which are able to offer many kinds of services. In the project finance business banks may offer two kind of services: advisory services and financing services.

As regards the role of financial advisor banks may assist public or private parties to promote projects. The following financial services might be provided by banks in the project finance business:

- analysis of technical aspects of the project (product, target market, competition, risks, etc.);

- analysis of regulatory and legal aspects;

- due diligence;

- risk sharing package;

- preparation of business plan and sensitivity analysis; 
- quantification of financial supports and identification of fund providers;

- evaluation of debt capital and equity capital in the project;

- organization and negotiation of financing terms (arranging).

As regards the role of financing services provider banks may mainly offer debt capital. They rarely offer equity capital. The activities concern mainly:

- underwriting debt capital;

- provision of syndicated loans;

- provision of equity capital;

- provision of guarantees;

- provision of financial support to issue project bonds and raise equity capital in the financial markets.

The project finance has two sources of funds: debt and equity. Debt capital is usually provided by commercial banks and international investment banks. Equity capital is usually provided by project sponsors and outside equity investors, such as commercial banks, investment funds specializing in project finance equity, venture capital and private equity vehicles. Banks are the largest providers of debt capital in project finance and the financial structure of the project (leverage ratio) is very important in convincing bankers to provide capital. It implies that banks must pay particular attention to the evaluation of the credit risk of the project. The failure of the project, and the subsequent borrowers' insolvency, may damage lenders heavily.

Project finance is characterized by an high leverage financing scheme. It is possible to achieve much higher leverage ratios than sponsors could sustain on their own balance sheets. In addition, project finance loans on average have a longer term than corporate loans. The traditional debt-based financing model is the bank loan. It is the traditional way to raise long-term funding for long-term projects. A new debt-based financing model is the issue of project bonds (Scannella, 2012). Using financial techniques and financial market conventions for project appraisal, design, and financial structure, project bonds might represent an innovative way to perform the function of financial intermediation instrument and long-term project financing instrument.

The assessment of economic and financial feasibility of the project made by the banks should primarily evaluate the expected economic return of the project on medium and long term, rather than focusing on collaterals provided by sponsors or third parties. To assess the "bankability" of a project is necessary to carry out a feasibility study. A bank, before starting the assessment process, has to evaluate the existence of key (base) elements to participate in a project finance. Banks have to differentiate bankable projects from not bankable ones.

Preliminary test of project practicability (viability test) is the first step for banks. The project should be technically feasible and economically viable (Esty, 2003; Fabozzi \& Nevitt, 2000; Yescombe, 2002). A "static" analysis of the project focuses on assets characteristics, tangibility and marketability of corporate assets, as well as firm's solvency ratios. In the standard corporate lending the lender has security over tangible assets. A "dynamic" analysis is necessary in funding project finance because lender's primary security is the future revenue stream of the project. It is a different type of analysis that focuses on the expected economic and financial returns associated with the project. In particular, a lender should deeply evaluate the degree of innovation of the project, the professional skills of people who will execute and manage the project, the capabilities, competences, and knowledge of firms involved in the project, the reaction of the target market to the introduction of new services and products. The implementation of a dynamic perspective of analysis of projects to be finance implies a "paradigm shift" in the bank lending assessment process (standard corporate lending vs. project finance lending).

Lending to a project exposes banks to credit risk. It is the typical risk in lending business. It refers to the borrower's ability to service its debt. The borrower is usually a special purpose vehicle (SPV) that is not permitted to perform any function other than developing, owning, and operating the project. Such credit risk exposure involves every kind of loans in project finance. Credit risk is most simply defined as the potential that a bank borrower will fail to meet its obligations in accordance with agreed terms. In a limited meaning of the "credit risk", it affects the extreme case of insolvency, namely the fact that debtor does not meet his payments. Credit risk definition can be enlarged including the reduction of creditworthiness. Even this reduction does not automatically translate into insolvency, however, it could increase the probability of insolvency. The payment may ultimately be made, but credit risk is a concern because the delay in receiving payments is costly. 
In a wider perspective, credit risk refers to the likelihood that the borrower will default or fail to make timely payments of principal and interest. Credit risk should be measured not with reference to a single binomial distribution ("default" vs. "no default") but with reference to a distribution of different levels of insolvency probability, in which the insolvency event is only the extreme event that could occur in the future.

Generally, the loan agreement in the project finance sets some possible "events of default" that allow lenders to take action against the project company. Once an event of default has occurred, the project company is no longer able to manage the project without lender involvement. These events do not put the project in default automatically. A decision has to be made by the lender after the event of default has occurred. As correctly argued by Yescombe (2002, p. 319) typical events of default could be the followings:

- the project company fails to make any payment under the financing documentation on its due date;

- the project company does not fulfill any of its covenants or undertakings under the finance documentation;

- there is any change in the ownership or control of the project company prior to an agreed date;

- the project company is subject to a court judgment for more than a certain amount;

- insufficient funding remains to complete construction of the project;

- any permit or license is revoked;

- the project is abandoned;

- any party defaults under a project contract.

Over the last decade, banks have invested a lot of resources in modeling the credit risk arising from their loans to project finance business, thanks to the implementation of the New Basle Capital Accord (2006). The revised Capital framework is more risk sensitive than the 1988 Accord. The new supervisory regulation aims to strengthen the soundness and stability of banks by adopting more risk sensitive capital requirements. It imposes a strict control over the bank lending policies. A significant innovation is the greater use of risk assessments provided by bank's internal rating systems. It has promoted the adoption of stronger risk management practices by banks. These advanced risk management practices aim to produce quantified measures of risk and economic capital, allowing banks to use internal credit risk models for regulatory capital purposes.

Credit exposure to project finance business is classified as a form of "specialized lending" (Basle Committee on Banking Supervision, 2006, p. 53) for the assessment of bank regulatory capital requirements. Credit exposures have to be classified as a form of specialized lending when:

- the exposure is typically to an entity (often a special purpose vehicle) which was created specifically to finance and/or operate physical assets;

- the borrower has little or no other material assets or activities, and therefore little or no independent capacity to repay the obligation, apart from the income that it receives from the assets being financed;

- the lender has a substantial degree of control over the assets and the income that it generates in accordance with the terms of the obligation;

- the primary source of repayment of the obligation is the income generated by the assets.

In accordance with the economic literature and professional practice, the New Basle Capital Accord (2006, p. 53) defines project finance as a method of funding in which the lender looks primarily to the revenues generated by a single project, both as the source of repayment and as security for the exposure. The lender is usually paid solely or almost exclusively out of the money generated by the contracts for the facility's output. The borrower is usually a special purpose vehicle that is not permitted to perform any function other than developing, owning, and operating the project.

Due to its unique financial characteristic, the credit risk assessment in project finance lending is particularly complex. Basically, the credit risk of project finance loans is affected by the timing and uncertainty of project cash flows. The main components of credit risk (probability of default, loss given default, and exposure at default) are closely connected with the nature and characteristics of the project, the economic sector of the project, the guarantees afforded to creditors, the potential alternative use of the assets that belong to the special purpose vehicle.

Project finance loans are structured in such a way that repayment of the loan depends principally on the cash flow generated by the asset rather than the credit quality of the borrower (Basle Committee on Banking Supervision, 2001). For this reason loans possess unique loss distribution and risk characteristics. Such credit 
exposures are treated separately from the corporate exposure. Basle Committee on Banking Supervision has proposed a specific regulatory treatment for these exposures (specialized lending).

In contrast with corporate exposures, there is no common industry standard for the estimation of credit risk in project finance lending. Every project has unique characteristics, unique financing schemes, and different risk sharing mechanisms that allocate risks among different parties involved (Esty, 2004). In addition, to calculate rigorous probability of defaults is necessary to base such calculations on valuable databases. Nevertheless, historical loan performance data for project finance exposures are scarce. Furthermore, defaults in project finance are quite rare because the failure of the project company generally involves a debt restructuring or a takeover by a new project company. Project finance exposures are characterized by few time series of defaults and losses. So, it is unlikely that a bank may rely on historic estimates of probability of defaults (PD) and loss given defaults (LGD) for the portfolio of project finance loans. Project finance operations usually have a complex structure. It implies that project finance rating is primarily based on future cash flows expectations rather than on historical data.

Under the previous Capital Accord (1988) there was no difference between corporate finance and project finance in measuring bank capital requirements. On the contrary, the New Capital Accord (2006) has recognized such differences. Project finance loans are classified as "specialized lending", an asset class different from the "corporate lending". The Basle Committee has proposed different methodologies for the estimation of the risk components: standardized approach, internal rating-based (IRB) approach, and supervisory slotting criteria approach (SSCA).

\section{Credit Risk in Project Finance: The New Regulatory Capital Requirements Framework}

The first operation that a bank must take to implement the New Basel Capital Accord is the classification of the credit exposure. In the project finance class, the main determinant of the credit risk is the variability of cash flows. The PD and LGD are therefore interconnected and depend on the revenues generated by the financed assets (Gatti, 2008; Marchetti, 2009; Sorge, 2004). The character of project finance is primarily related to the future revenues of the project.

In the "standardized approach" banks must continue to assimilate project finance exposures to corporate exposures: project finance is considered as a normal financing transaction. Banks must use a coefficient related to the external rating assigned to the SPV, otherwise a coefficient equal to $100 \%$. It means that when project finance loans are unrated banks have to use $100 \%$ risk weight. The bank's supervisory authority, however, can classify the project finance loans as "category at higher risk", for which is defined a coefficient higher than that required for corporate finance. It assumes that in some cases project finance loans could be riskier than corporate loans. This implies an higher capital requirement in the project finance lending business.

Within the internal rating-based approach (IRB), however, project finance exposures must be classified in specialized lending portfolio and partly within the corporate portfolio. Banks may classify their loans into risk categories using their own internal data. In general, to calculate capital requirements to cover expected and unexpected losses for specialized lending exposures, banks must apply the same rules established for corporate exposures. The derivation of risk-weighted assets depends on estimates of PD, LGD, EAD and, in some cases, effective maturity (M), for a given exposure. With the IRB approach for project finance loans banks may incorporate specific risk profiles into capital requirements standards.

Banks that meet the requirements for the estimation of PD are able to use the foundation approach to corporate exposures to derive risk weights for all classes of project finance exposures. LGD is set by the Authority equal to $45 \%$, as corporate exposures. Within the IRB advanced approach, banks that meet the requirements for the estimation of PD, LGD, and EAD are able to use the advanced approach to corporate exposures to derive risk weights for project finance exposures. Consequently, banks must determine the project rating as corporate exposures, using its own rating system procedure to estimate credit risk components. Within IRB approaches, therefore, the rules relating to corporate exposures were extended, without any change, even to the project finance loans without considering the peculiarity of this type of transaction, which would influence the default definition and estimation of risk factors: PD, LGD, and EAD (Sorge \& Gadanecz, 2004). In both cases, the capital requirements would be based on a framework established by the banking authority, which would define the relationship between PD, LGD, and risk weights. As argued by Esty (2004, p. 3), in most cases, banks using the IRB approaches would have equal or lower capital requirements than banks using the standardized approach.

Banks have to overcome many difficulties in estimating the risk factors of a project finance transaction. They have to take into account different aspects and risks of the transaction, such as financial structure of the project, operating and constructing risks, legal and regulatory issues, political and administrative constraints, 
environmental and technological implications, etc. The risk implications of project finance lending are determined by the application of complex mathematical models that are highly affected by the ability to predict the future cash flow expectations of the project. These models have to be appreciated by banks and supervisors. Furthermore, it might be difficult to calibrate them in practice. This problem has caused severe difficulties for some banking institutions. Complex valuation and implementation problems may arise particularly with reference to small and medium banking firms. Consequently, only banks that have good databases and good historical data, and a good organizational structure, implement the internal rating-based approach in the project finance lending business.

Finally, banks that do not meet the requirements for the estimation of PD under the corporate foundation approach for their specialized lending assets are required to map their internal risk grades into five supervisory categories. Each category has a specific risk weight. This version is termed the "supervisory slotting criteria approach".

The supervisory slotting criteria approach (SSCA) is a qualitative method. It is a simplified rating method. Banks must assign credit to one of the following levels: strong, good, satisfactory, weak and default. The supervisory authority provides a scheme through which banks can analyze risk factors of the project, and then classify exposures into 5 levels (a specific risk weight is associated to each level). Risk weights for unexpected losses that are associated with each supervisory category are described in table 1. Each supervisory category broadly corresponds to a range of external credit assessments, as outlined in table 2.

At national level, supervisors may allow banks to assign preferential risk weights of $50 \%$ to "strong" exposures, and $70 \%$ to "good" exposures, when they have a remaining maturity of less than 2.5 years or the supervisor determines that banks' underwriting and other risk characteristics are substantially stronger than specified in the slotting criteria for the relevant supervisory risk category.

For project finance exposures subject to the supervisory slotting criteria, the expected losses amount are determined by multiplying $8 \%$, the risk-weighted assets (using the appropriate risk weights), and the EAD. Risk weights for project finance are outlined in table 3. Banks must assign exposures to their internal rating grades based on their own criteria, systems and processes, subject to compliance with minimum requirements. Banks must then map the internal rating grades into five supervisory rating categories. In other words, the outcome of the slotting approach (expected loss) is mapped into a slotting category. The general assessment factors and characteristics exhibited by exposures in every supervisory category are provided by the Basle Committee on Banking Supervision (2006).

The Committee recognizes that the criteria that banks use to assign exposures to internal grades will not perfectly align with criteria that define supervisory categories. However, banks must demonstrate that their mapping process has resulted in an alignment of grades consistent with the characteristics of supervisory categories. Banks should take special care to ensure that any overrides of their internal criteria do not render the mapping process ineffective.

Table 1 . Supervisory categories and unexpected losses risk weights for specialized lending exposures

\begin{tabular}{ccccc}
\hline Strong & Good & Satisfactory & Weak & Default \\
\hline $\mathbf{7 0 \%}$ & $\mathbf{9 0 \%}$ & $\mathbf{1 1 5 \%}$ & $\mathbf{2 5 0 \%}$ & $\mathbf{0 \%}$ \\
\hline
\end{tabular}

Source: Basle Committee on Banking Supervision (2006).

Table 2. Correspondence between each supervisory category and a range of external credit assessments

\begin{tabular}{lllll}
\hline Strong & Good & Satisfactory & Weak & Default \\
\hline BBB- or better & BB + or BB & BB- or B + & B to C- & Not applicable \\
\hline
\end{tabular}

Source: Basle Committee on Banking Supervision (2006).

Table 3. Risk weights for specialized lending

\begin{tabular}{lllll}
\hline Strong & Good & Satisfactory & Weak & Default \\
\hline $\mathbf{5 \%}$ & $\mathbf{1 0 \%}$ & $\mathbf{3 5 \%}$ & $\mathbf{1 0 0 \%}$ & $\mathbf{6 2 5 \%}$ \\
\hline
\end{tabular}

Source: Basle Committee on Banking Supervision (2006). 
The criteria provided by the Committee are linked to practices already in use by intermediaries and rating agencies with regard to asset-backed lending programs (Gatti 2008; Marchetti, 2009). For example, Standard \& Poor's has developed 5 levels of analysis and the first project finance industry database: project level risks, sovereign risk, institutional risk, force majeure risk, credit enhancements. The first level corresponds to financial strength criteria and transaction characteristics of the New Bank Capital Accord, while the second and third level correspond to political and legal environment of the New Bank Capital Accord.

Table 2 makes a comparison between risk weights useful to calculate the unexpected losses for project finance exposures with the SSCA and those useful to calculate the unexpected losses for corporate exposures in the standardized approach. It means that the two rating methods deliver comparable results.

In brief, the treatment of project finance exposures under the New Basle Capital Accord has boosted banks to implement sophisticated credit risk analysis models into the credit assessment value chain, and develop in-house technical experts. Banks may develop their own models for specialized lending exposures in accordance with minimum standards for estimating PD and LGD. In this sense, a bank is able to shift from elementary approaches to sophisticated ones (as, for example, Monte Carlo simulations). Slotting approaches in project finance exposures are required when it is not possible to meet the above minimum criteria.

Over the time, based on economic literature, operating experience, and regulatory standards, major banks have developed their own project finance credit risk models. Instruments and approaches for the evaluation of credit risk in the project finance lending are a recent development and raise particular issues, both at theoretical and practical level. This paper has contributed to shed light on both levels.

\section{Conclusion}

Project finance is an innovative model of financing projects. It is a useful technique for financing large and long-term projects with relatively predictable cash flows. Project finance has typically an high leveraged financial scheme. Cash flow and risk analysis are the two main crucial aspects of every project finance transaction. Banks have increased the use of quantitative models to analyze default risks and loan losses in project finance lending. Banks must be able of evaluating risk factors of the project, and the assumptions used in the prediction of the future cash flows. In the project finance lending practices look primarily to the expected income stream of the project.

The paper highlights the features of credit risk assessment in project finance lending, and how the bank regulatory framework affects it. Project finance involves a higher degree of sophistication in credit risk analysis than normal loans. This consideration suggested a tentative conclusion regarding the regulatory implications of the project finance in the banking business. The new bank regulatory capital requirement framework recognizes such important differences between corporate and project finance lending.

The appreciation of the risk factors and, in a wider view, the credit risk evaluation process of the project finance package, are fundamental elements not only for the success of project finance loans market, but also for the bank capital adequacy, soundness, safety, and stability. A deeper understanding of the credit risk in project finance lending affects the allocation of financial resources across asset classes in a bank portfolio.

In the capital adequacy framework, project finance is defined as a form of specialized lending. Cash flows generated by the project are the main sources of repayment. The regulatory treatment of the project finance is investigated in the paper. Current bank approaches to estimate rating in project finance are put under substantial pressures. A qualitative method, named the supervisory slotting criteria approach, might support banks to implement a cash flow oriented model to appreciate credit risk in the project finance business. 
Table 4. A comparison between risk weights for unexpected losses in the New Bank Capital Accord

\begin{tabular}{cccc}
\hline \multicolumn{2}{c}{ STANDARDISED } & \multicolumn{2}{c}{$\begin{array}{r}\text { SUPERVISORY SLOTTING CRITERIA } \\
\text { APPROACH - SL EXPOSURES }\end{array}$} \\
\hline APPROACH-CORPORATE EXPOSURES & Risk weights & CATEGORY & Risk weights \\
\hline RATING & $20 \%$ & Strong & $70 \%$ \\
AAA & $20 \%$ & Strong & $70 \%$ \\
AA+ & $20 \%$ & Strong & $70 \%$ \\
AA & $20 \%$ & Strong & $70 \%$ \\
AA- & $50 \%$ & Strong & $70 \%$ \\
A+ & $50 \%$ & Strong & $70 \%$ \\
A & $50 \%$ & Strong & $70 \%$ \\
A- & $100 \%$ & Strong & $70 \%$ \\
BBB + & $100 \%$ & Strong & $70 \%$ \\
BBB & $100 \%$ & Strong & $70 \%$ \\
BBB- & $100 \%$ & Good & $90 \%$ \\
BB + & $100 \%$ & Good & $90 \%$ \\
BB & $100 \%$ & Satisfactory & $115 \%$ \\
BB- & $150 \%$ & Satisfactory & $115 \%$ \\
B + & $150 \%$ & Weak & $250 \%$ \\
Da B a C- & Not applicabile & Default & 0 \\
D & & & \\
\hline
\end{tabular}

Marchetti (2009) based on Basel Committee on Banking Supervision (2006).

\section{Acknowledgement}

The author acknowledges Dr. Mara Albanese for research assistance in writing the section 3.

\section{References}

Altug, S., Ozler, S., \& Usman, M. (2002). The Role of Lender Behaviour in International Project finance. Economic Theory, 19. http://dx.doi.org/10.1007/s001990000159

Basle Committee on Banking Supervision. (2001). Working Paper on Internal Ratings-Based Approach to Specialized Lending Exposures. Bank for International Settlement, October.

Basle Committee on Banking Supervision. (2006). International Convergence of Capital Measurement and Capital Standards. A Revised Framework. Bank for International Settlement, July.

Beidleman, C. R., Fletcher, D., \& Veshosky, D. (1990). On allocating risk: the essence of project finance. Sloan Management Review, 31(3).

Brealey, R. A., Cooper, I. A., \& Habib, M. A. (1996). Using Project Finance to Fund Infrastructure Investments. Journal of Applied Corporate Finance, 3. http://dx.doi.org/10.1111/j.1745-6622.1996.tb00296.x

Comana, M. (2003). Il project financing per le opere di media dimensione. Milan: Franco Angeli.

Esty, B. C. (2002). Returns on Project-Financed Investments: Evolution and Managerial Implications. Journal of Applied Corporate Finance, 15. http://dx.doi.org/10.1111/j.1745-6622.2002.tb00342.x

Esty, B. C. (2003). The Economic Motivations for Using Project Finance, Harvard Business School, Working Paper.

Esty, B. C. (2004). Basel II: Assessing the Default and Loss Characteristics of Project Finance Loans, Harvard Business School, Working Paper.

Fabozzi, F., \& Nevitt, P. (2000). Project Financing. London: Euromoney Books.

Finnerty, J. D. (2007). Project Financing. Asset-Based Financial Engineering. New Jersey: John Wiley \& Sons.

Gatti, S. (2008). Project Finance in Theory and Practice. Burlington: Academic Press.

Imperatori, G. (2003). Il project financing. Milan: Il Sole 24 Ore.

Khan, M. F. K., \& Parra, R. J. (2003). Financing Large Projects: Using Project Finance Techniques and Practises. Essex: Pearson Education.

Marchetti, P. (2009). Il project finance. Rome: Bancaria Editrice. 
Nevitt, P. K. (1988). Project financing. Rome: Laterza.

Orgeldinger, J. (2006). Basel II and Project Finance. The Development of a Basel II-Conforming Rating Model. Journal of Structured Finance, 11(4). http://dx.doi.org/10.3905/jsf.2006.614085

Scannella, E. (2012). Project Finance in the Energy Industry: New Debt-based Financing Models. International Business Research, 5(2). http://dx.doi.org/10.5539/ibr.v5n2p83

Sorge, M. (2004). The Nature of Credit Risk in Project Finance. BIS Quarterly Review. December.

Sorge, M., \& Gadanecz, B. (2004). The Term Structure of Credit Spreads in Project Finance. BIS Working Papers, n. 159.

Wynant, L. (1980). Essential Elements of Project Financing. Harvard Business Review, 58(3).

Yescombe, E. R. (2002). Principles of Project Finance. San Diego: Academic Press. 